TILTAI, 2016, 1, 239-252, ISSN 1392-3137 (Print), ISSN 2351-6569 (Online)

\title{
SOCIAL MEDIAS: OPPORTUNITIES FOR LEARNING / TEACHING ENGLISH IN HIGHER EDUCATION
}

\author{
Irena Darginavičienė, Violeta Navickienė \\ Klaipèda University
}

\begin{abstract}
The greatest achievement of technology, the Internet, not only changed the lifestyles of the world population, but also created unheard of before opportunities for learning and teaching foreign languages. The development of digital technology provided the important shift from the informational Web 1.0 to the social Web 2.0, which allows involving users in active communication and collaboration with each other. The number of social media websites keeps constantly increasing, which makes them available to learners all over the world. The estimated number of social network users worldwide is $1.79 \mathrm{bn}$. Students' familiarity with online social media has been reported in this article. The opportunities for applying the Internet websites in active learning / teaching of languages depend to a great extent on what sites learners are accustomed to using and how often. The findings on the use of social media websites are obtained from the survey completed by two samples of students of Klaipeda University. The research reveals that learners use (constantly or often) Facebook, YouTube, Twitter, Google, and Wikipedia. However collaborative editing, social bookmarking, weblogs and conversational sites are never used or even not familiar. The data imply that it is essential to increase learners' training in application of social sites. Some statistical correlations between the data for both samples have been found by using the Software Package for Social Sciences (SPSS). There is either $99 \%$ or $95 \%$ probability that an observed Pearson's correlation coefficients are not a chance finding. It means that the findings might be applied beyond the studied samples.

KEY WORDS: social media, learning/teaching English, statistical analysis.
\end{abstract}

\begin{abstract}
Anotacija
Interneto atsiradimas ne tik pakeite žmonių gyvenseną visame pasaulyje, bet ir sukūré palankias sąlygas mokytis užsienio kalbų. Kompiuterinès technologijos pažanga nuo informacinès programinès įrangos Web 1.0 iki socialinès Web 2.0 leido vartotojams aktyviai bendrauti ir bendradarbiauti. Socialinių medijų tinklalapių skaičius nuolat auga: šiuo metu jis siekia 1,79 milijardo. Šiame straipsnyje aptariama, kokias socialines medijas naudoja aukštųju mokyklų studentai. Informacija surinkta atlikus studentų apklausą, kurioje dalyvavo Klaipédos universiteto dviejų specialybių studentai. I anketą įtrauktos plačiai visuomenei žinomos ir mažiau žinomos medijos. Rezultatai atskleidè, kad studentai nuolat arba dažnai naudojasi „Facebook“, „YouTube“, „Twitter“, „Google“ ir „Wikipedia“. Vis dèlto dauguma studentų nèra naudoję ar girdèję apie redagavimo, blogų ir pokalbių socialinius tinklalapius. Tai liudija, kad siekiant sẻkmingai aukštojoje mokykloje mokyti(-s) užsienio kalbų būtina supažindinti studentus su šių medijų taikymu. Straipsnyje aprašomi statistikos tyrimai pasitelkus SPSS programinę ịrangą. Kompiuteriniai skaičiavimai rodo, kad koreliacijos tarp dviejų ištirtų imčių tikimybės yra $95 \%$ ar $99 \%$. Pearsono koreliacijos koeficientų vertės rodo rezultatų suderinamumą, t. y. rezultatai nèra atsitiktiniai ir gali būti taikomi didesnèms imtims.

PAGRINDINIAI ŽODŽIAI: socialinès medijos, anglų kalbos mokymas(-is), statistikos tyrimas.
\end{abstract}

DOI: http://dx.doi.org/10.15181/tbb.v73i1.1276 


\section{Introduction}

The number of social media websites keeps constantly increasing, which makes them available to learners all over the world. The development of digital technology provided the important shift from the informational websites to the social ones. This allows involving users in active communication and collaboration with each other. The opportunities for applying online websites in active learning / teaching of languages depend on the learners' familiarity with the usage of social media. The aim of the current research is to find out if the respondents are familiar with social media websites and how often they use them. The results are obtained from the survey completed by the students of Klaipeda University. The findings imply that it is essential to increase learners' training in application of social websites.

\section{Literature background}

In 2014 the world commemorated the 25th anniversary of the creation of the World Wide Web by Sir Tim Berners-Lee, who submitted a proposal for an information management system in order to develop a radical new way of linking and sharing information. Since then, this system has been known as the World Wide Web (Bernes-Lee, 1989). New technologies changed the way of human communication and made 'digital literacies' a must (Hockly, 2012). In the $21^{\text {st }}$ century, students need skills that include "information, media and technology". The Internet provided great opportunities for learning and teaching foreign languages. In 2012, C. Dudeney and N. Hockly presented a thorough review of how specific developments in information and communication technologies impacted teaching of English over the past three decades. The major shift was the transition from the Web 1.0 to the Web 2.0, which ensured that online users with no programming skills could produce creative resources. In contrast to Web 1.0, which refers to the original informational web, Web 2.0 refers to the social web. It is a grouping of newer generation of social technologies, whose users are actively involved in communicating and collaborating with each other as they build connections and communities across the web. The term itself was coined by Dale Dougherty in 2004 and popularized by Tim O'Reilly (2012). Therefore, the Web 2.0 is not in opposition to the Web 1.0 - it is its development. In the Web 2.0 everyday users generate and share content. It enables groups of users to socialize, collaborate, and work with each other. In recent years social networking systems have received much attention in higher education. In the UK, increasing numbers of young people made use of Facebook (Oradini and Saunders, 2007). This means that social networking systems have the capability to deliver a platform for learning where the student is potentially at the center of activities. 
The key findings on social networking site usage and adoption from the Pew Research Center's Internet Project are as follows (Duggan and Smith, 2013): a number of online adults now use a social networking site of some kind. Facebook is the dominant social networking platform in the number of users, but a striking number of users are now diversifying onto other platforms. The number of Facebook users now is 1.55 bn (Statistics data, 2016). $42 \%$ of online adults now use multiple social networking sites. In addition, Instagram users are nearly as likely as Facebook users to check in to the site on a daily basis.

According to M. Duggan and A. Smith (2013), $71 \%$ of teens use Facebook and $52 \%$ - Instagram, which is shown in the Reference Chart 1 below.

\section{Facebook, Instagram and Snapchat Top Social Media Platforms for Teens}

$\%$ of all teens 13 to 17 who use ...

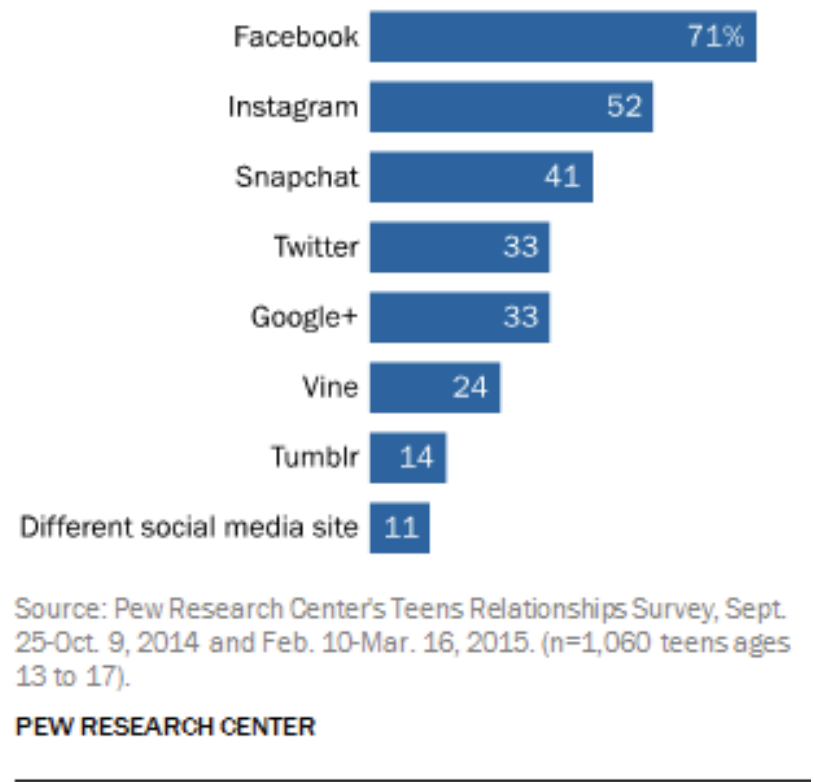

Reference Chart 1. Statistics of social media platforms for teens

The statistics show that the number of social network users (2016) worldwide is increasing and is expected to reach $2.44 \mathrm{bn}$ in 2018. According to the earlier research by M. Lenhart, et al. (2007), the use of social media - from blogging to online social networking - became very popular among teenagers. $93 \%$ of teens use the Internet, and more of them use it for social interaction; $42 \%$ of teens who use social networking sites also say they blog. $70 \%$ social networking teens report 
reading the blogs of others, and $76 \%$ have posted comments to a friend's blog on a social networking site. Email continues to lose its importance among teens as texting, instant messaging, and social networking sites facilitate more frequent contact with friends. Only $14 \%$ of all teens report sending emails to their friends every day, making it the least popular form of daily social communication.

Reference Chart 2 on Social Media Sites shows the percentage of online users who used different social media in 2012 and 2013. The $1^{\text {st }}$ columns display the percentage of users in 2012, and the $2^{\text {nd }}$ columns - in 2013. Facebook is the most popular site: the number of users increased from $67 \%$ to $71 \%$. Other sites are less popular, but there were more users in 2013 than in 2012. LinkedIn is especially popular among college graduates. Twitter and Instagram have particular appeal to younger adults.

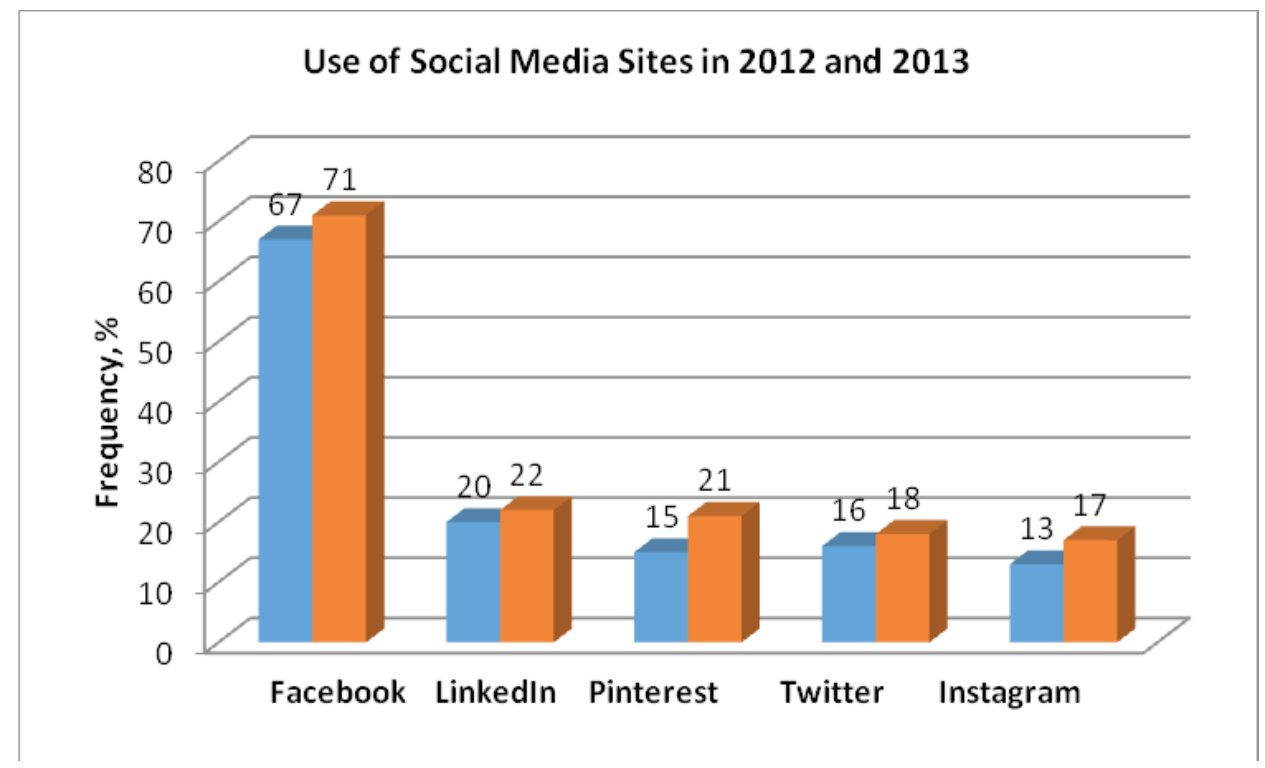

Reference Chart 2. (After M. Duggan and A. Smith, Social Media Update). 1st bars display the data in 2012, 2nd bars show the data in 2013.

Reference Chart 3 presents the data of online survey that was carried out in 2014. It is obvious that users engage with major social networks predominantly via mobile. It is seen that desktop usage ( $1^{\text {st }}$ columns) has largely remained lower in 2013 for top media sites while mobile usage ( $2^{\text {nd }}$ columns) continues to increase. In fact, this is a very new trend in social networking: mobile / desktop divide continues to grow. Among the largest social networks, only Linkedin and Tumblr maintain a majority share on desktop, while newer social networks such as Instagram, Pinterest and Snapchat are almost exclusively mobile. 


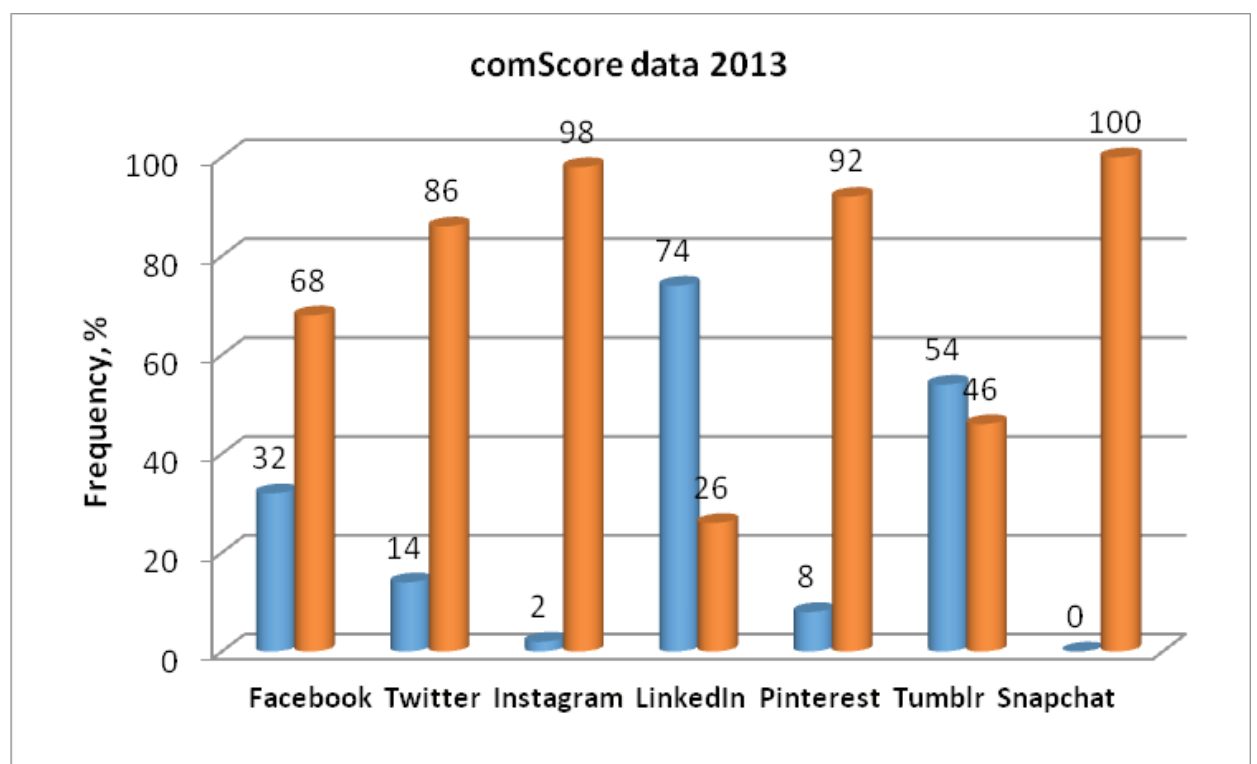

Reference Chart 3. ComScore data published in 2014 on desk use of media sites versus mobile use in 2013. $1^{\text {st }}$ bars show desk use, $2^{\text {nd }}$ bars show mobile use

A study into the use of Web 2.0 technologies for learning and teaching in Higher Education (Franklin \& Harmelen, 2007) provided recommendations on implementing Web 2.0 technologies. They examined progress at four universities (Warwick, Leeds, Brighton and Edinburgh), which have taken a strategic approach, and implemented Web 2.0 services in different ways. Universities had to address a wide variety of issues in implementing technologies. These issues include: what types of tools to implement (Wikis, blogs, e-portfolios, social bookmarking), how to monitor the systems for inappropriate and offensive use, how to encourage uptake and use, how the use of Web 2.0 tools will affect learning and teaching.

In the research by K. Mitchell (2012) the students joined Facebook for social reasons: they were able to communicate with friends, learn English through Facebook with few difficulties. Facebook, which was launched in 2004, facilitates the interaction between the students and the teachers. Created in 2005 YouTube, which is a video-sharing website, can also be successfully used for language learning purposes.

It has already been mentioned that the current media sites include Facebook, YouTube, Twitter, Wikipedia, Instagram, LinkedIn, weblogs. In the literature review, H. S. Mahdi (2014) analyzed the impact of Computer-Mediated Communication Environments on foreign language learning. 
J. Gikas and M. Grant (2013) explored teaching and learning using mobile computing devices such as cellphones, smartphones and social media. Their qualitative research study focused on students from three universities across the US. Data were collected through student focus group interviews. Two themes emerged: (a) advantages of mobile computing devices for student learning and (b) frustrations from learning with mobile computing devices. The use of social media created opportunities for interaction and collaboration, as well as allowed students to engage in content creation and communication.

M. A. Kenny (2015) suggested why to use media in language learning / teaching. The pedagogical arguments include authentic and independent learning, high motivation and fun, meaningful interaction (peer-peer, student-instructor), vast resources of authentic audio and video materials. Some ways of using social media like Facebook, Twitter, YouTube, or blogs are described.

However, information on application of social websites for learning languages in higher education is rather scarce. To fill in the gap it is important to find out which social sites are favoured by students. This information will be helpful seeking to implement social medias for language learning / teaching at university level.

\section{Respondents}

The respondents in this study are 50 students, who study English for Specific Purposes (30) and English for Philology (20) at Klaipeda University. The design of the English courses reflects the students' needs for their future profession. The courses are adjusted to the requirements for a Bachelor degree. The level of students' proficiency is either $\mathrm{B} 2$ or $\mathrm{C} 1$ according to the Common European Framework of Reference for Languages.

\section{Research methodology}

The findings have been obtained from the survey completed by the students of two specializations. The survey has been designed in accordance with accepted standards of constructing surveys (Dornyei, 2003). It contains 8 references on social media websites, which are shown in Table 1. Students responded to the survey on a 5-point Likert's scale ranging from "constantly" (5), "very often" (4), "sometimes" (3), "never" (2), "unknown site" (1). The responses have been processed by a means of the Software Package for Social Sciences (SPSS) in order to determine if there are any correlations between the current data. 
Table 1. Survey on social media websites

\begin{tabular}{|l|l|l|l|l|l|}
\hline \multicolumn{1}{|c|}{ Social network websites } & $\begin{array}{c}\text { Use } \\
\text { constant- } \\
\text { ly (5) }\end{array}$ & $\begin{array}{c}\text { Use often } \\
\text { (4) }\end{array}$ & $\begin{array}{c}\text { Use } \\
\text { some- } \\
\text { times (3) }\end{array}$ & $\begin{array}{c}\text { Never } \\
\text { use (2) }\end{array}$ & $\begin{array}{c}\text { Not familiar } \\
\text { with the site } \\
\text { (1) }\end{array}$ \\
\hline $\begin{array}{l}\text { Media sharing websites (Google, } \\
\text { DropBox, MediaFire, 4Shared) }\end{array}$ & & & & & \\
\hline $\begin{array}{l}\text { Media manipulation website } \\
\text { (YouTube) }\end{array}$ & & & & & \\
\hline $\begin{array}{l}\text { Collaborative editing websites } \\
\text { (Collabedit, Firepad) }\end{array}$ & & & & & \\
\hline $\begin{array}{l}\text { Social bookmarking websites } \\
\text { (slashdot.org, reddit.com, } \\
\text { stumbleupon.com, digg.com) }\end{array}$ & & & & & \\
\hline Wikipedia & & & & & \\
\hline $\begin{array}{l}\text { Conversational sites (ELLLO, } \\
\text { 1-Language) }\end{array}$ & & & & & \\
\hline $\begin{array}{l}\text { Social network websites } \\
\text { (Facebook, Twitter) }\end{array}$ & & & & & \\
\hline Weblogs (personal or public) & & & & & \\
\hline
\end{tabular}

\section{Results and discussion}

This part of the article reports the findings of the survey and analyzes the key points that emerged.

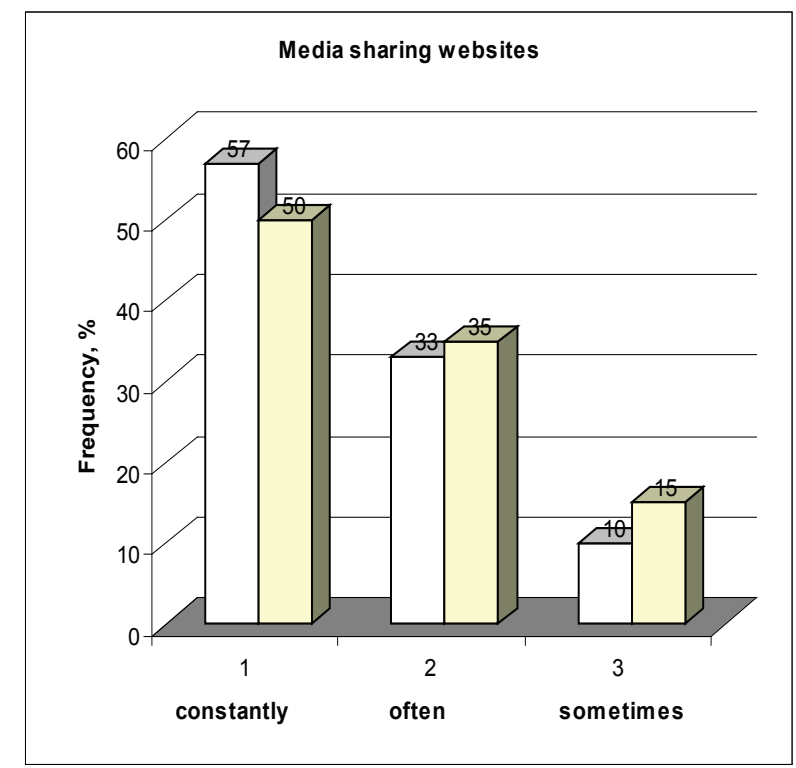

Chart 1. Frequency of student's responses on media sharing websites such as Google. $1^{\text {st }}$ bars show frequency of responses by ESP group, $2^{\text {nd }}$ bars show frequency of responses by Philology group 
Chart 1 presents the data on media sharing websites. It is obvious that responses of both groups are very similar. Majority of learners use these websites either constantly or often, and the most common is Google.

Google is universally acknowledged to be the most used search engine on the World Wide Web, handling more than three billion searches every day (Google search, 2016).

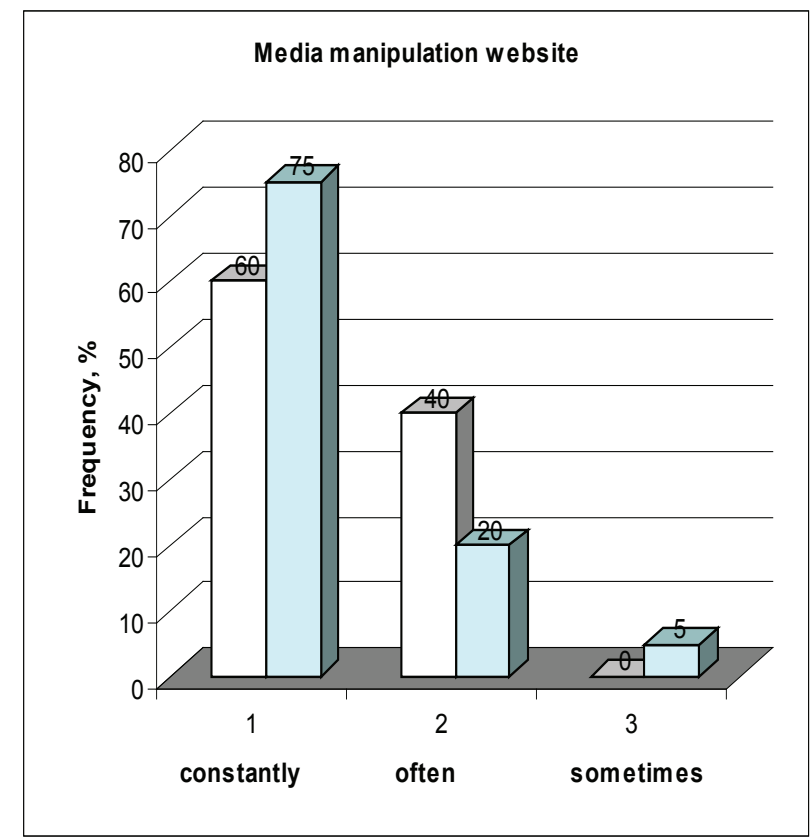

Chart 2. Frequency of student's responses on media manipulation websites such as YouTube

$1^{\text {st }}$ bars show frequency of responses by ESP group, $2^{\text {nd }}$ bars show frequency of responses by Philology group.

Chart 2 displays the results of using media manipulation websites such as YouTube. The students of Philology demonstrate a significant preference in using it constantly.

YouTube is very well known to all internet users. It allows billions of people to discover, watch and share originally created videos, provides a forum for people to connect, inform, and inspire others across the globe and acts as a distribution platform for content creators (YouTube media, 2016).

As it can be seen in Chart $3.87 \%$ of ESP group use this website constantly in comparison to $45 \%$ of Philology group. 
Wikipedia is a well known as multilingual, web-based, free content encyclopedia, which is written basically by anonymous unpaid volunteers. It means that anyone can write and make changes to Wikipedia articles (Wikipedia about, 2016). For this reason, not all information is absolutely reliable and should not be taken for granted.

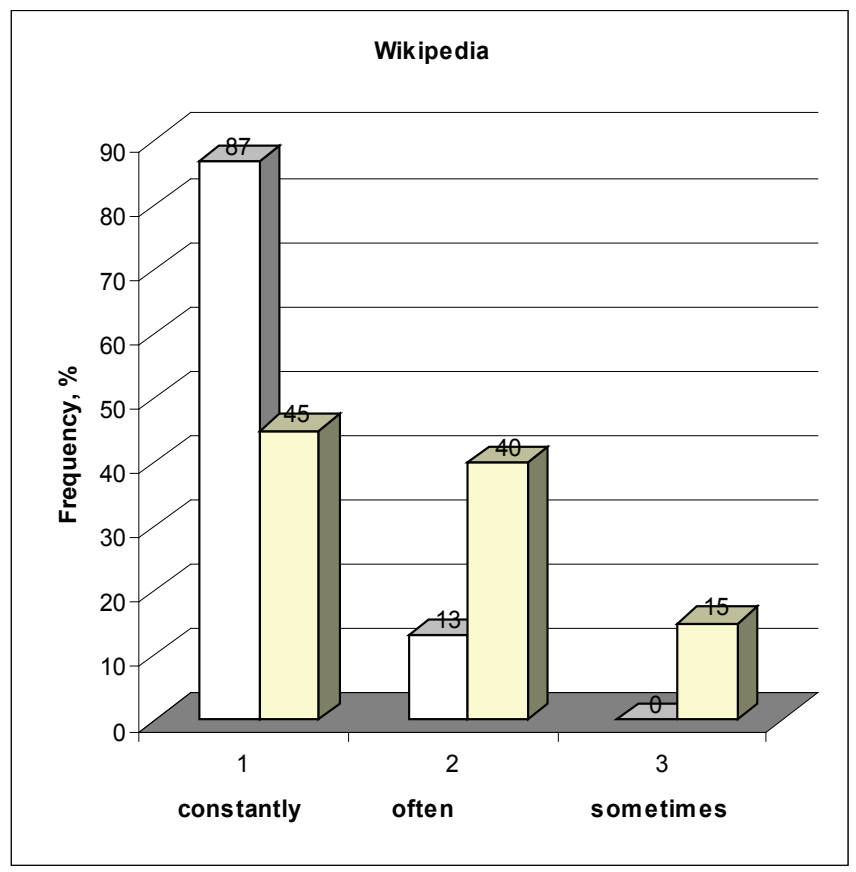

Chart 3. Frequency of student's responses on Wikipedia. $1^{\text {st }}$ bars show frequency of responses by ESP group, $2^{\text {nd }}$ bars show frequency of responses by Philology group

Chart 4 shows frequencies of responses to social network websites. ESP group displays preference to use these sites constantly $(80 \%)$, while only about half of Philology group (45\%) uses it constantly.

Facebook users can exchange messages, post status updates and photos, share videos, use various apps, etc. (Facebook about, 2016). In August 2016, there were 1.18 billion monthly active users of Facebook. Another common social website is Twitter, which claims that its mission is to give everyone the power to create and share ideas and information instantly (without barriers), which attracts a great number of users (Twitter about, 2016). 
Irena Darginavičienè, Violeta Navickienè

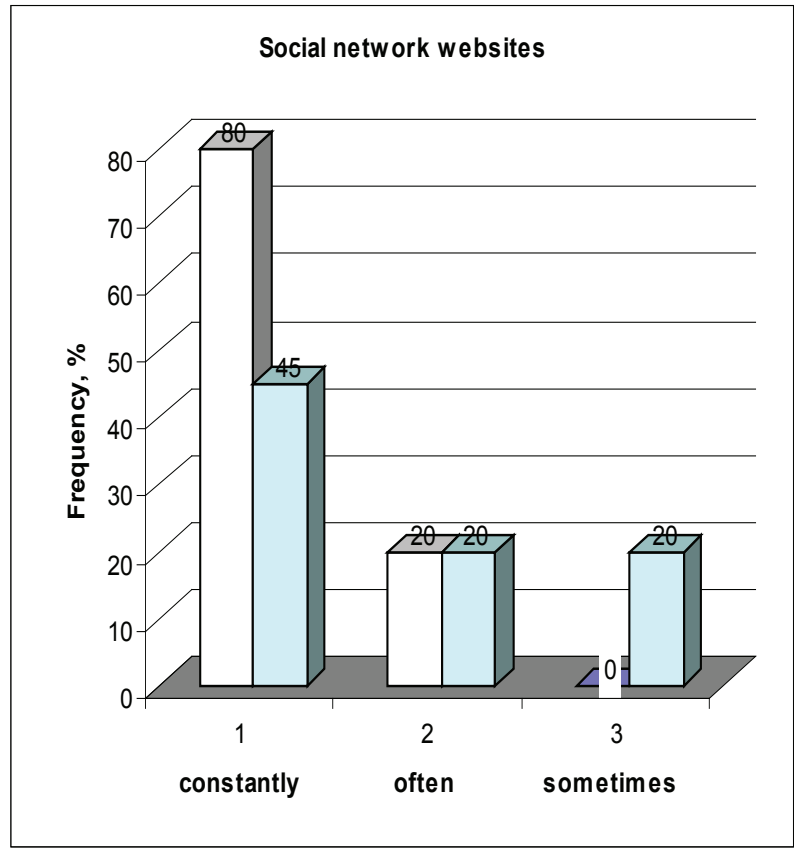

Chart 4. Frequency of student's responses on social network websites such as Facebook and Twitter.

$1^{\text {st }}$ bars show frequency of responses by ESP group, $2^{\text {nd }}$ bars show frequency of responses by Philology group

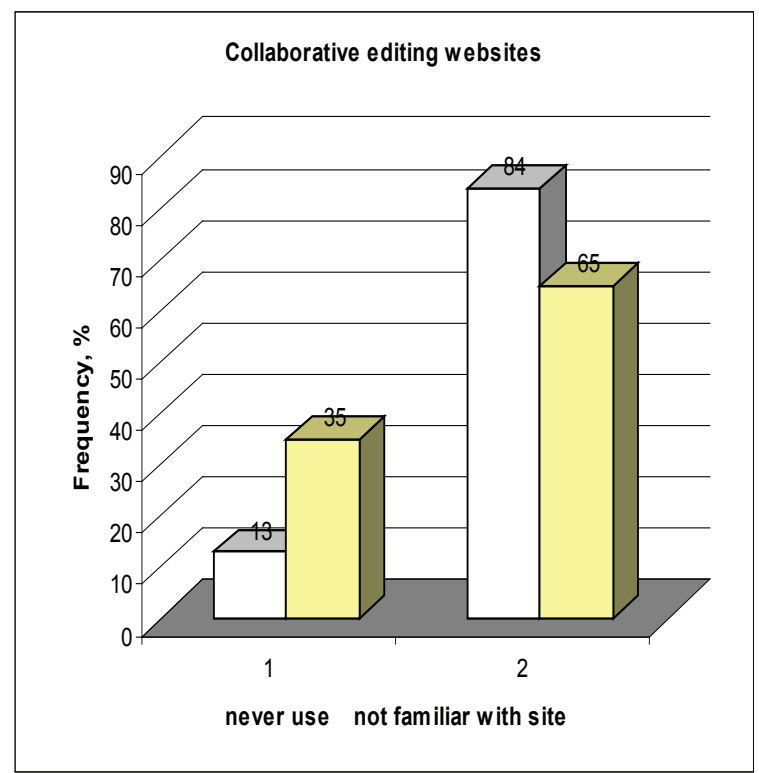

Chart 5. Frequency of students' responses on collaborative editing websites such as Collabedit or Firepad. $1^{\text {st }}$ bars show frequency of responses by ESP group, $2^{\text {nd }}$ bars show frequency of responses by Philology group 
Chart 5 clearly demonstrates that students of both groups either never use the websites or are not familiar with them.

Collabedit is an online code editor that lets people collaborate in real-time (Collabedit about, 2016). Its useful features are text editor, collaborative coding, technical call interviews, syntax highlighting. Firepad is a text editing website and is recommended as alternative software to Windows (Firepad about, 2016).

Conversational websites prove to be basically unfamiliar to students of both groups as it is demonstrated by Chart 6 . Just a few students use them sometimes: 3 students (10\%) from ESP group and 1 student (5\%) from Philology group.

Conversational websites are beneficial to language learners as they allow them to communicate with native speakers, which include face-to face chats, correspondence (pen-pal), video chat (Skype). ELLLO provides free listening, reading and vocabulary practice (Elllo about, 2016).

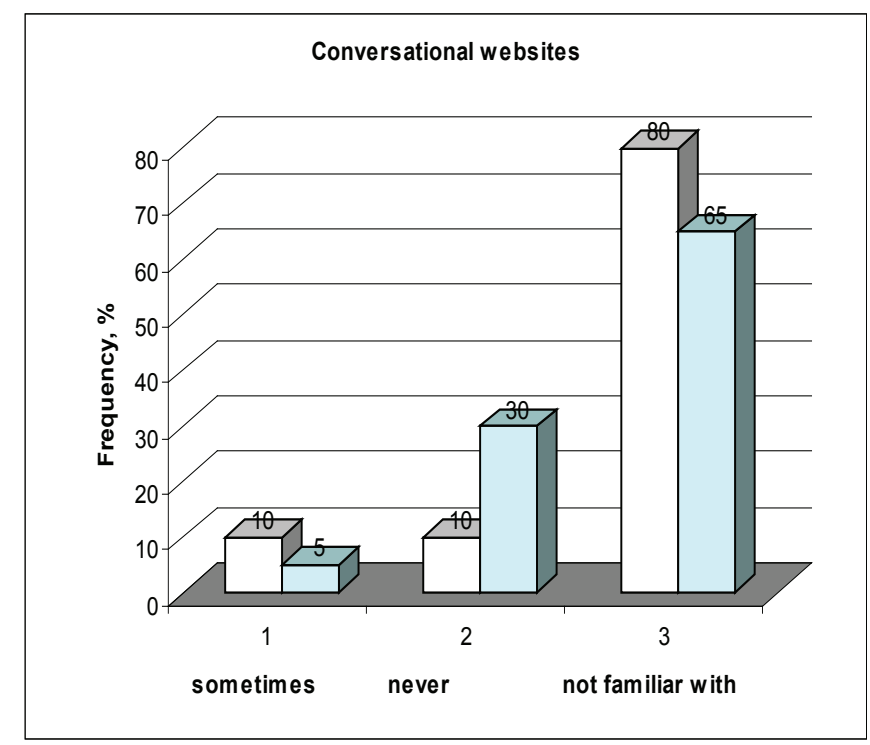

Chart 6. Frequency of student's responses on conversational websites such as ELLLO.

$1^{\text {st }}$ bars show frequency of responses by ESP group, $2^{\text {nd }}$ bars show frequency of responses by Philology group

Similarly as conversational sites, weblogs are not favored by majority of students which is shown in Chart 7. Just $20 \%$ (4 students out of 20) of Philology students sometimes use them.

Weblogs are personal (or public) websites which are useful for recording written work online and self-assessing progress in learning languages.

Blogging is one of the most popular online activities all over the world. Online newspapers and governments' websites contain numerous blogs with opportunities for people to write their comments. 
Summing up the obtained results, it can be concluded that some websites are familiar to students. This information is displayed by Charts 1, 2, 3, and 4. However, some websites are basically unknown, i.e. Charts 5,6 , and 7 .

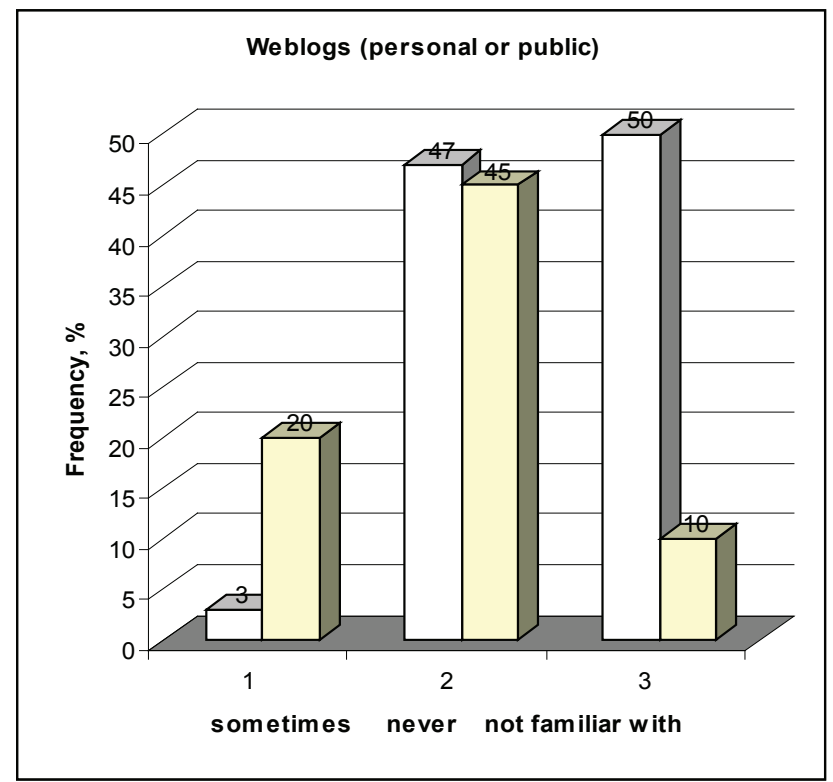

Chart 7. Frequency of student's responses on use of weblogs (personal or public). $1^{\text {st }}$ bars show frequency of responses by ESP group, $2^{\text {nd }}$ bars show frequency of responses by Philology group

\section{Statistical Processing of Data}

Statistical processing by a means of the Statistical Package for the Social Sciences (SPSS) allows ascertaining how comparable and reliable the data are. Internal consistency reliability is usually estimated by computing Cronbach's Alpha coefficient. Results are reliable if the value of Cronbach's Alpha coefficient is at least .70. The second step in correlation analysis is to compute correlation coefficients rho, which shows the degree of relationships between the samples. In order to determine whether a correlation coefficient indicates a real relationship, it is necessary to compute the probability, i.e. the value of significance level Sig $p$. Statistical significance with $p$ values of .01 or .05 indicates that there is either $99 \%$ or $95 \%$ probability that an observed correlation coefficient is not a chance finding, i.e. it is meaningful. Once the value of Sig $p$ has been established, the meaningfulness of the correlation coefficient depends on its magnitude. The larger the coefficient, positive or negative, the stronger the relationship, so that a correlation that is close to one, either positive or negative, indicates a very strong relationship, while coefficients that are near zero indicate very weak relationships. 
In this research, the responses shown in Charts 1, 2, 3 and 4 have been processed statistically. The values of the Cronbach's Alpha coefficient are between 0.87 and 0.93 , which is considered acceptable in Social Science research settings, i.e. the obtained results are reliable. The normality of distributions of responses has been checked by computing Kolmogorov-Smirnov Tests for both samples. As the distributions proved to be normal, so the Pearson's correlation coefficients rho have been computed.

Table 2. Pearson's correlation coefficients rho and Significance Level Sig $p$. *Correlation is significant at the 0.05 level (probability $95 \%$ ), **Correlation is significant at 0.01 level (probability $99 \%$ ).

Table 2. Statistical processing results

\begin{tabular}{|l|ll|ll|l|}
\hline \multicolumn{1}{|c|}{ Social network websites } & \multicolumn{2}{|l|}{$\begin{array}{l}\text { Use constantly } \\
\text { rho Sig } p\end{array}$} & \multicolumn{2}{|l|}{$\begin{array}{l}\text { Use often } \\
\text { rho Sig } p\end{array}$} & \multicolumn{2}{|l|}{$\begin{array}{l}\text { Use sometimes } \\
\text { rho Sig } p\end{array}$} \\
\hline $\begin{array}{l}\text { Media sharing websites } \\
\text { (Google) }\end{array}$ & $.896^{* *}$ & .000 & $.895^{* *}$ & .000 & $.892^{* *} \quad .000$ \\
\hline $\begin{array}{l}\text { Media manipulation website } \\
\text { (YouTube) }\end{array}$ & $.845^{* *}$ & .001 & $.823^{* *}$ & .002 & - \\
\hline Wikipedia & $.850^{*}$ & .015 & $.839^{*}$ & .025 & - \\
\hline $\begin{array}{l}\text { Social network websites } \\
\text { (Facebook, Twitter) }\end{array}$ & $.848^{*}$ & .017 & $.895^{* *}$ & .001 & - \\
\hline
\end{tabular}

The results of statistical processing of responses that are displayed in Charts 1 , 2, 3, and 4, are presented in Table 2. In some cases, good correlations are obtained. Pearson's correlation coefficients rho vary between .848 and .896 , and significance levels Sig $p$ are either 0.01 or 0.05 , i.e. probabilities are $99 \%$ or $95 \%$. Missing data in Table 2 means there are no correlations between the samples.

The students' familiarity with major social websites suggests that opportunities of employing the Internet resources for learning / teaching English have great perspectives. The application of social websites in higher education is great challenge to learners and language practitioners.

\section{Conclusions}

The reported data of the current research reveal that students are familiar with well known websites like Google, Facebook, YouTube, and Wikipedia. Charts 1 to 4 demonstrate that learners use these sites constantly or often. Statistical processing of survey data indicates that there are good correlations between responses of both samples of respondents: Pearson's correlation coefficients vary between .848 and .896 , and probabilities are $99 \%$ or $95 \%$, which implies that results are not accidental and can be extended beyond the investigated samples. However, the majority of students have never used or even heard of collaborative editing, conver- 
sational and bookmarking websites, which are important platforms for language learning. It is essential to increase training in application of these social websites for learning / teaching English since they have a great potential for making changes in higher education. Students need to master novel sites to enable them to collaborate on projects, converse online, create images, edit videos, write blogs, and share bookmarks using the Internet tools. The contemporary generation of students has grown up with digital technology. They have different ways of thinking and processing materials, which should make social websites technologies invaluable in helping change learning and teaching methods.

\section{Received 20160102 \\ Approved for publishing 20160307}

\section{References}

ComScore data. (2014). Website: http://www.comscoredatamine.com/2014/04/users-engage-with-major-socialnetworks-predominantly-via-mobile/

Collabedit about. (2016). Website: http://collabedit.com/

Dornyei, Z. (2003). Questionnaires in Second Language Research. Lawrence Erlbaum Associates, Inc.

Dudeney, C., Hockly, N. (2012). ICT in ELT: How Did We Get Here and Where Are We Going? ELT Journal, Vol. $66 / 4$, p. 533-542.

Duggan, M., Smith, A. (2013). Social Media Update. Website: http://www.pewinternet.org/2013/12/30/socialmedia-update-2013/

Facebook about. (2016). Website: https://en.wikipedia.org/wiki/Facebook

Firepad about. (2016). Website: http://alternativeto.net/software/firepad/?license=opensource

Ello about. (2016). Website: http://www.elllo.org/english/home.htm

Franklin, T., van Harmelen, M. (2007). Web 2.0 for Content for Learning and Teaching in Higher Education. Website: http://web2-content-learning-teaching.pdf

Gikas, J., Grant, M. M. (2013). Mobile computing devices in higher education: Student perspectives on learning with cellphones, smartphones \& social media. Internet and Higher Education, Vol. 19, p. 18-26.

Google search. (2016). Website: https://en.wikipedia.org/wiki/Google_Search

Hockly, N. (2012). Digital Literacies. ELT Journal, Vol. 66/1, p. 108-112.

Kenny, M. A. (2015). Using Social Media in Language Teaching and Learning: Some Pedagogical and Technological Considerations. Website: http://www.onevoiceforlanguages.com/uploads/2/4/6/7/24671559/using_social_media_in_language_teaching_and_learning.pdf

Lenhart, A., Madden, M., Smith, A., Macgill, A. (2007). Teens and Social Media. Website: http://www.pewinternet.org/2007/12/19/teens-and-social-media/

Mahdi, H. S. (2014). The Impact of Computer-Mediated Communication Environments on Foreign Language Learning: a Review of the Literature. Teaching English with Technology, Vol. 14(2), p. 67-86. Website: http://www.tewtjournal.org

Mitchell, K. (2012). A Social Tool: Why and How ESOL Students Use Facebook. CALICO Journal, Vol. 29(3), p. $471-493$.

Statistics: Number of social network users worldwide. (2016). Website: http://www.statista.com/statistics/278414/ number-of-worldwide-social-network-users/

Twitter about. (2016). Website: https://about.twitter.com/company.

Oradini, F., Saunders, G. (2007). The Use of Social Networking by Students and Staff in Higher Education. Website: http://www.eife-1.org/publications/proceedings/ilf08/contributions/improving-quality-of-learning-withtechnologies/Oradini_Saunders.pdf

O'Reilly, T. (2012). Various Things I Have Written. Website: http://www.oreilly.com/tim/

Statistics data. (2016). Website: http://www.statista.com/topics/1164/social-networks/

Tim Bernes-Lee Proposal. (1989). Website: http://info.cern.ch/Proposal.html

YouTube media. (2016). Website: https://www.youtube.com/yt/about/

Wikipedia about. (2016). Website: https://en.wikipedia.org/wiki/Wikipedia:About). 